\title{
Wastewater treatment in an integrated laboratory system
}

\author{
Silviya Lavrova*, Bogdana Koumanova \\ University of Chemical Technology and Metallurgy, 8 Kliment Ohridsky blvd., 1756 Sofia, Bulgaria
}

Received: 19 November 2016

Accepted: 22 January 2017

Published online: 5 March 2017

\begin{abstract}
Integrated laboratory system consisted of three stages - activated sludge reactor, biofilter and subsurface vertical flow wetland was used to treat two types of wastewaters differed in their generation and pollution. Wastewaters from a pig farm as well as from a landfill site for domestic wastes were used in the experiments. The BOD/COD ratio of the wastewaters from a pig farm and from the landfill leachate was 0.5 and 0.07 , respectively. In the first stage of the integrated system was achieved COD removal ( $48 \%$ for the piggery wastewater for 3 days and $62.3 \%$ for the landfill leachate after 4 days). BOD removal $(55.6 \%)$ for the piggery wastewater was achieved in 3 days and $24.9 \%$ - for the landfill leachate after 4 days. The decreasing of organics at aerobic conditions was accompanied with the ammonium ions decreasing - 1.5 times for the piggery wastewater and 4 times for the leachate. In the second stage - biofilter without aeration, an additional organic loading decreasing was achieved. The COD decreased from $820.9 \mathrm{mg} / \mathrm{dm}^{3}$ to $274.3 \mathrm{mg} / \mathrm{dm}^{3}$ for piggery wastewater and for the leachate - from $869.5 \mathrm{mg} / \mathrm{dm}^{3}$ to $423.6 \mathrm{mg} / \mathrm{dm}^{3}$. The BOD values decreased from $384.1 \mathrm{mg} / \mathrm{dm}^{3}$ to $106.8 \mathrm{mg} / \mathrm{dm}^{3}$ for the piggery wastewater and for leachate - from $117.8 \mathrm{mg} / \mathrm{dm}^{3}$ to $57.4 \mathrm{mg} / \mathrm{dm}^{3}$. The ammonium ions were eliminated from both types of wastewaters. In the third stage (subsurface vertical flow wetland) the emission standards for discharge into the sewage collection systems or into the water bodies are met.
\end{abstract}

Keywords: piggery wastewater, landfill leachate, activated sludge reactor, biofilter, vertical-flow wetland

\section{Introduction}

The point source of pollution of the surface and groundwater, such as landfills and pig farms, can discharge wastewater if their quality is responsive to the emission standards for discharge into the sewage collection systems or into the water bodies. The high concentrations of chemical oxygen demand (COD), biochemical oxygen demand (BOD), ammonium nitrogen and odour are typical for this kind of wastewaters. The quality of the piggery wastewater varies depending on whether the solid fraction is preliminary separated prior to further treatment (Li et al. 2016). In comparison with landfill leachates, the piggery wastewaters contain high concentrations of easily biodegradable compounds. The composition of the landfill leachates is more complex. They also contain various toxic and nonbiodegradable compounds. The quality of the leachates varies during the landfill exploitation

\footnotetext{
* Corresponding author: Silviya Lavrova
}

e-mail: engeco2001@uctm.edu 
(Bhalla et al. 2013). The discharge of the piggery wastewater and landfill leachate into aquatic environment without preliminary treatment will cause serious eutrophication and other unfavourable effects (Melnyk et al. 2014, Yamamoto et al. 2008).

The main purpose for treatment of such kind of wastewaters is the nitrogenous compounds removal accompanied with a significant decrease of COD and BOD values. There are different biological (aerobic and anaerobic) methods for this kind of compounds removing (Jetten et al. 1999, Joo et al.2006, Kim et al. 2016, Lavrova and Koumanova 2007, Lavrova and Koumanova 2014, Limoli et al. 2016, Mojiri et al. 2016, Renou et al. 2008, Sheridan et al. 2002, Strous et al. 1997, Wang et al. 2016, Zhang et al. 2008). Air stripping of ammonia, coagulation, flocculation and precipitation for preliminary treatment of the wastewater are also used. These techniques require large capital investments, greater energy consumption, application of additional quantities of reagents, etc. (Wiszniowski et al. 2006). Other methods such as reverse osmosis and adsorption only convert pollutants and do not solve the environmental problem. Recently advanced oxidation methods like $\mathrm{UV} / \mathrm{H}_{2} \mathrm{O}_{2}, \mathrm{UV} / \mathrm{O}_{3}, \mathrm{UV} / \mathrm{TiO}_{2}$ are used for mineralization of recalcitrant organics but they are not economically acceptable for large-scale application. A significant decrease of overall high organic loaded wastewater treatment cost could be obtained by the combination of different biological processes.

The aim of this study was to compare the treatment efficiency of integrated laboratory system, consisted of an aerobic activated sludge reactor, a biofilter and a reactor type subsurface vertical flow wetland for two types of wastewaters - piggery wastewater and landfill leachate.

\section{Materials and Methods}

\subsection{Wastewater characteristics}

Two different types of wastewater were used in the experiments - piggery wastewater and landfill leachate.

\section{Piggery wastewater}

The piggery wastewater was taken from a pig farm located in the south-western part of Bulgaria. After collection, the raw slurry was settled overnight because untreated effluent typically contains high concentrations of solids, organic matter, and nutrients. Table 1 summarizes the characteristics of the influent piggery wastewater.

\section{Landfill leachate}

The landfill leachate was taken from a 15 years old landfill situated in the north-western part of Bulgaria. The characteristics of the landfill leachate used in the experiments are presented in Table 2.

Tab. 1 Piggery wastewater characteristics.

\begin{tabular}{cc}
\hline Parameter & Value (mean $\pm \mathrm{SD})$ \\
\hline $\mathrm{COD}\left(\mathrm{mg} / \mathrm{dm}^{3}\right)$ & $2049 \pm 40.9$ \\
$\mathrm{BOD}\left(\mathrm{mg} / \mathrm{dm}^{3}\right)$ & $1037 \pm 32.9$ \\
$\mathrm{NH}_{4}-\mathrm{N}\left(\mathrm{mg} / \mathrm{dm}^{3}\right)$ & $406 \pm 22.4$ \\
$\mathrm{NO}_{3}-\mathrm{N}\left(\mathrm{mg} / \mathrm{dm}^{3}\right)$ & 0 \\
$\mathrm{pH}$ & $7.3-8.3$ \\
\hline
\end{tabular}

Tab. 2 Landfill leachate characteristics.

\begin{tabular}{cc}
\hline Parameter & Value $($ mean $\pm \mathrm{SD})$ \\
\hline $\mathrm{COD}\left(\mathrm{mg} / \mathrm{dm}^{3}\right)$ & $2867 \pm 47.8$ \\
$\mathrm{BOD}\left(\mathrm{mg} / \mathrm{dm}^{3}\right)$ & $207 \pm 9.3$ \\
$\mathrm{NH}_{4}-\mathrm{N}\left(\mathrm{mg} / \mathrm{dm}^{3}\right)$ & $232 \pm 40.6$ \\
$\mathrm{NO}_{3}-\mathrm{N}\left(\mathrm{mg} / \mathrm{dm}^{3}\right)$ & $1.6 \pm 0.5$ \\
$\mathrm{pH}$ & $7.5-8.1$ \\
\hline
\end{tabular}


The COD value in the piggery wastewater was significantly lower than that in the landfill leachate, while BOD value in the piggery wastewater was fivefold higher than that in the landfill leachate. The BOD/COD ratio of the piggery wastewater and of the landfill leachate was 0.5 and 0.07 , respectively. Obviously, the easy biodegradable substances in the piggery wastewater are predominant in comparison with those in the landfill leachate. Typically piggery wastewater has extremely high concentration of the ammonium nitrogen, which is result of the animals' vital activity. In the wastewater used for the experiments the $\mathrm{NH}_{4}-\mathrm{N}$ concentration was $406 \pm 22.4 \mathrm{mg} / \mathrm{dm}^{3}$. In the landfill leachate their concentration was almost twice lower $\left(232 \pm 40.6 \mathrm{mg} / \mathrm{dm}^{3}\right)$ because of the landfill age. It is well known that with the development of the operational period of the landfill, the $\mathrm{NH}_{4}-\mathrm{N}$ concentration is decreasing. It is also believed that ammonia is mainly released during the organic matter decomposition (Burton and Watson-Craik 1998). Thus ammonia appears to be a good indicator for organic nitrogen in the leachate (Lee et al. 2010). The piggery wastewater has not contained nitrate nitrogen because it was taken soon after its generation and without preliminary treatment. Because of oxidation of ammonium ions in the reservoir, where it was collected for a longer period of time, the landfill leachate contained nitrate nitrogen. The $\mathrm{pH}$ of the piggery wastewater and the landfill leachate was without significant difference.

\subsection{Integrated laboratory system}

The integrated laboratory system used in the experiments is shown in Fig. 1. It is consisted of three main treatment units - an activated sludge reactor, a biofilter and a reactor type subsurface vertical-flow wetland. The laboratory reactors were made of Plexiglas.

Activated sludge reactor (ASR). The dimensions of the activated sludge reactor are $195 \mathrm{~mm}$ in diameter and $650 \mathrm{~mm}$ in height. The air was blown into the system through three diffusers, situated at the bottom of the ASR. The aerobic activated sludge (AS) was taken from a municipal wastewater treatment plant.

\section{Biofilter}

The dimensions of the biofilter are $123 \mathrm{~mm}$ in diameter and $900 \mathrm{~mm}$ in height. It was filled with $800 \mathrm{~mm}$ layer of $7 \div 15 \mathrm{~mm}$ round gravel.

\section{Constructed wetland}

The reactor type subsurface vertical-flow wetland (SVFW) was planted with Phragmites australis and its dimensions are $123 \mathrm{~mm}$ in diameter and $900 \mathrm{~mm}$ in height. The reactor column was filled with $300 \mathrm{~mm}$ height bottom layer of $35 \div 55 \mathrm{~mm}$ round gravel and top layer with a height of 500 $\mathrm{mm}$ of $5 \div 25 \mathrm{~mm}$ gravel thus providing a media porosity of $31.5 \%$.

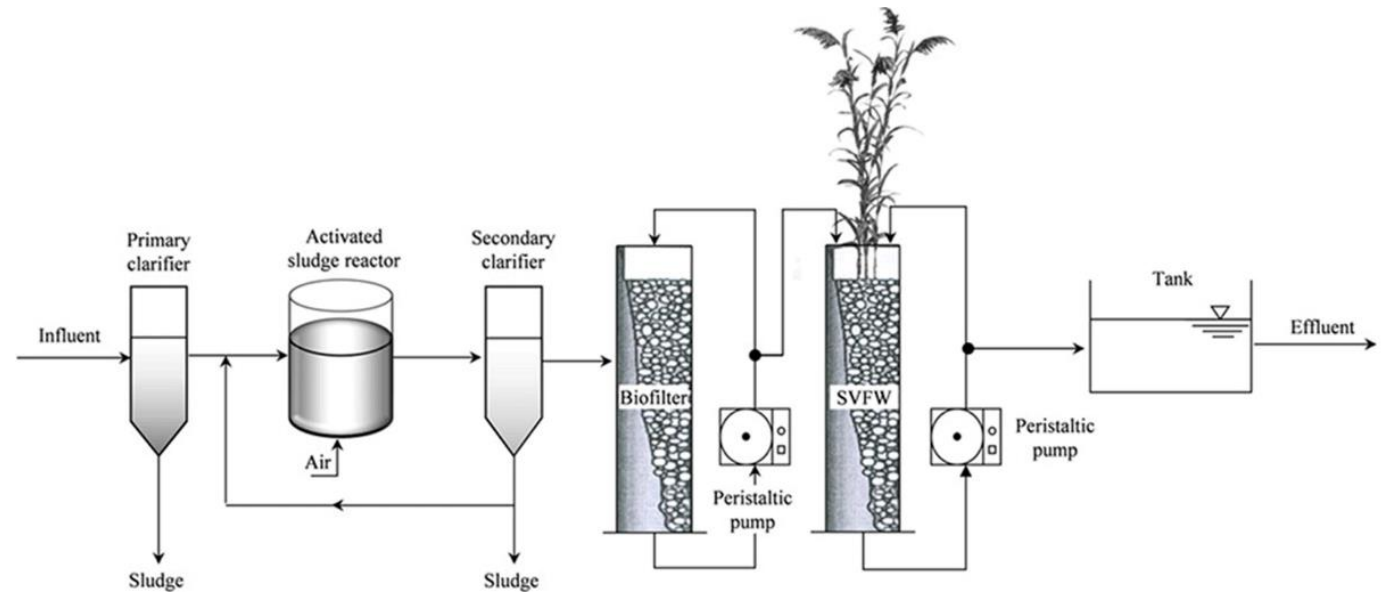

Fig. 1 Flow diagramme of the lab-scale integrated system. 


\subsection{Analytical methods and chemicals}

The parameters Chemical Oxygen Demand (COD), Biochemical Oxygen Demand (BOD), Ammonium Nitrogen $\left[\mathrm{NH}_{4}-\mathrm{N}\right]$ and Nitrate Nitrogen $\left[\mathrm{NO}_{3}-\mathrm{N}\right]$ were determined by standard methods, using pure reagents for analysis (American Public Health Association et al. 1992).

\subsection{Treatment of wastewater by integrated laboratory system}

\section{First stage}

After sedimentation in the primary sedimentation tank the wastewater flows into activated sludge reactor, using volume ratio of mixed liquid "activated sludge : wastewater" (AS:PS) $=1: 1$. The air was blown into the system through three diffusers, situated at the bottom of the ASR. Water samples were taken for determination of the $\mathrm{COD}, \mathrm{BOD}, \mathrm{NH}_{4}-\mathrm{N}$ and $\mathrm{NO}_{3}-\mathrm{N}$ values. After some decreasing of the initial values of the analyzed physicochemical parameters, wastewater flows into secondary sedimentation tank for clarifying.

\section{Second stage}

After clarifying the wastewater flows into the biofilter without aeration. Peristaltic pump ensures the water movement through the reactor with flow rate $45 \mathrm{~cm}^{3} / \mathrm{min}$. The system operated continuously in recirculation regime. The recirculation was performed at ratio of 1:2, giving $1 \mathrm{~h}$ water movement through the filter media and $2 \mathrm{~h}$ resting period of the water into the reactor (contact between the wastewater and the bed matrix). Water samples were taken daily for determination of the COD, BOD, $\mathrm{NH}_{4}-\mathrm{N}$ and $\mathrm{NO}_{3}-\mathrm{N}$ values. After reaching half COD decreasing, the wastewater flows into the next reactor.

\section{Third stage}

Young Phragmites australis, obtained from comparatively clean area, was planted in the reactor type subsurface vertical-flow wetland (SVFW). The SVFW operated continuously in recirculation regime too. The recirculation was performed at ratio of 1:2, giving $1 \mathrm{~h}$ water movement through the filter media and $2 \mathrm{~h}$ resting period of the water in the reactor (contact between the wastewater and the bed matrix). The flow rate of the system was $45 \mathrm{~cm}^{3} / \mathrm{min}$ and hydraulic loading was $0.38 \mathrm{~cm}^{3} / \mathrm{cm} . \mathrm{min}$. Effluent samples were taken daily for analyses of the COD, BOD, $\mathrm{NH}_{4}-\mathrm{N}$ and $\mathrm{NO}_{3}-\mathrm{N}$.

\subsection{Removal efficiency}

The removal efficiency was determined using the formula Eq. 1:

$$
R=100-\left(\frac{C_{t}}{C_{O}}\right) * 100 \quad(\%) \quad \text { Eq. } 1
$$

where $C_{t}$ is the concentration at time $t$ and $C_{o}$ is the initial concentration in $\mathrm{mg} / \mathrm{dm}^{3}$.

\section{Results and discussion}

Figure 2 shows the variation of the analysed parameters (COD, BOD, NH4-N and NO3-N), characterizing the wastewater quality during the experiments with piggery wastewater and landfill leachate. The piggery wastewater was treated in each stage as follows: 2 days in the activated sludge reactor, 3 days in the biofilter and 4 days in the subsurface vertical-flow wetland. The landfill leachate was treated in each stage as follows: 3 days in the activated sludge reactor, 5 days in the biofilter and 7 
days in the subsurface vertical-flow wetland. The reason was to obtain gradual reduction of the initial concentrations of the parameters of interest.

The BOD/COD ratio is an indicator of the proportion of biochemically degradable organic matter to total organic matter (Lee and Nikraz 2014). This ratio of the piggery wastewater and the landfill leachate was 0.5 and 0.07 , respectively. As a whole the $\mathrm{pH}$ values are closed to neutral zone which is important for the nitrifying bacteria.

\subsection{Piggery wastewater treatment}

Significant removal efficiency was achieved in the aerobic activated sludge reactor during the 2 days treatment of piggery wastewater. The COD and BOD values decreased with $48 \%$ and $55.6 \%$, respectively. The organics reduction in aerobic conditions was accompanied with the ammonium ions concentration decreasing $(77.8 \%)$ as well as their nitrification to nitrates. Significant increasing of the $\mathrm{NO}_{3}-\mathrm{N}$ concentration in this treatment stage was observed due to the intensive aeration in activated sludge reactor. Then the water flows to the bioreactor for three-day treatment.

During this period of time the COD concentration of the piggery wastewater decreased 3.9 times and high removal efficiency $(86.6 \%)$ was achieved with respect to the initial COD of the raw piggery wastewater. BOD values decreased 4.3 times and removal efficiency of $89.7 \%$ with respect to its initial concentration of the raw wastewater was achieved.

Less pronounced reduction of ammonium ion in the biofilter was observed. The concentration of $\mathrm{NH}_{4}-\mathrm{N}$ decreased 1.5 times. The nitrates concentration was reduced from $8.9 \mathrm{mg} / \mathrm{dm}^{3}$ to $7.3 \mathrm{mg} / \mathrm{dm}^{3}$. No significant denitrification was observed probably because the developed anoxic conditions in the biofilter are not sufficient in this case. Obviously, the addition of carbon source will be needed. The third stage of the integrated laboratory system is a subsurface vertical-flow wetland (SVFW) which was used for the wastewater polishing. There the COD values of the piggery wastewater decreased 3.6 times after 4 days of treatment. It was achieved $96.3 \%$ COD removal efficiency and $97.6 \%$ BOD removal efficiency with respect to the initial COD and BOD. Total elimination of ammonium ions from the piggery wastewater was achieved in the subsurface vertical-flow wetland for 3 days, but the total denitrification was not achieved.

\subsection{Landfill leachate treatment}

During the 3 days treatment of the landfill leachate in the activated sludge reactor the removal efficiency was $62.3 \%$ for COD and $24.9 \%$ for BOD, respectively. This minor efficiency according to BOD is probably due to the lower BOD/COD ratio (0.07) of the landfill leachate. Presumably the nonbiodegradable substances are those that inhibit the aerobic microorganisms' activity which leads to the lower treatment efficiency. The $\mathrm{NH}_{4}-\mathrm{N}$ concentration decreased with $73.3 \%$, which was accompanied with sharply increasing of the nitrate concentration. The initial $\mathrm{NO}_{3}-\mathrm{N}$ concentration in the landfill leachate was $1.6 \pm 0.5 \mathrm{mg} / \mathrm{dm}^{3}$ and for three days of oxidation their concentration increased up to 7.9 $\mathrm{mg} / \mathrm{dm}^{3}$. After initial reduction of the leachate pollution in the aerobic reactor, it enters the biofilter for further treatment, where the COD decreased 2.6 times for 5 days, and high removal efficiency of $85 \%$ was achieved with respect to the initial COD. The treatment of the landfill leachate in the biofilter leads to 2.7 times BOD deceasing and $71.9 \%$ removal efficiency with respect to the initial BOD of the raw landfill leachate. Less pronounced reduction of ammonium ion, contained in the landfill leachate, in the biofilter was also observed. The concentration of the $\mathrm{NH}_{4}-\mathrm{N}$ decreased 1.5 times also and in parallel with this was observed minimal nitrates reduction from $9.4 \mathrm{mg} / \mathrm{dm}^{3}$ to $7.5 \mathrm{mg} / \mathrm{dm}^{3}$. In the final stage of the integrated laboratory system - SVFW, the COD of the landfill leachate decreased 5.7 times after 7 days of treatment. It was achieved $97.4 \%$ removal efficiency with respect to the initial COD of the raw landfill leachate. $88.5 \%$ BOD removal efficiency was achieved in the SVFW for 4 days. 
Total elimination of ammonium ions from the piggery wastewater and the landfill leachate was achieved in the subsurface vertical-flow wetland for 7 days. In the SVFW total denitrification was not achieved.
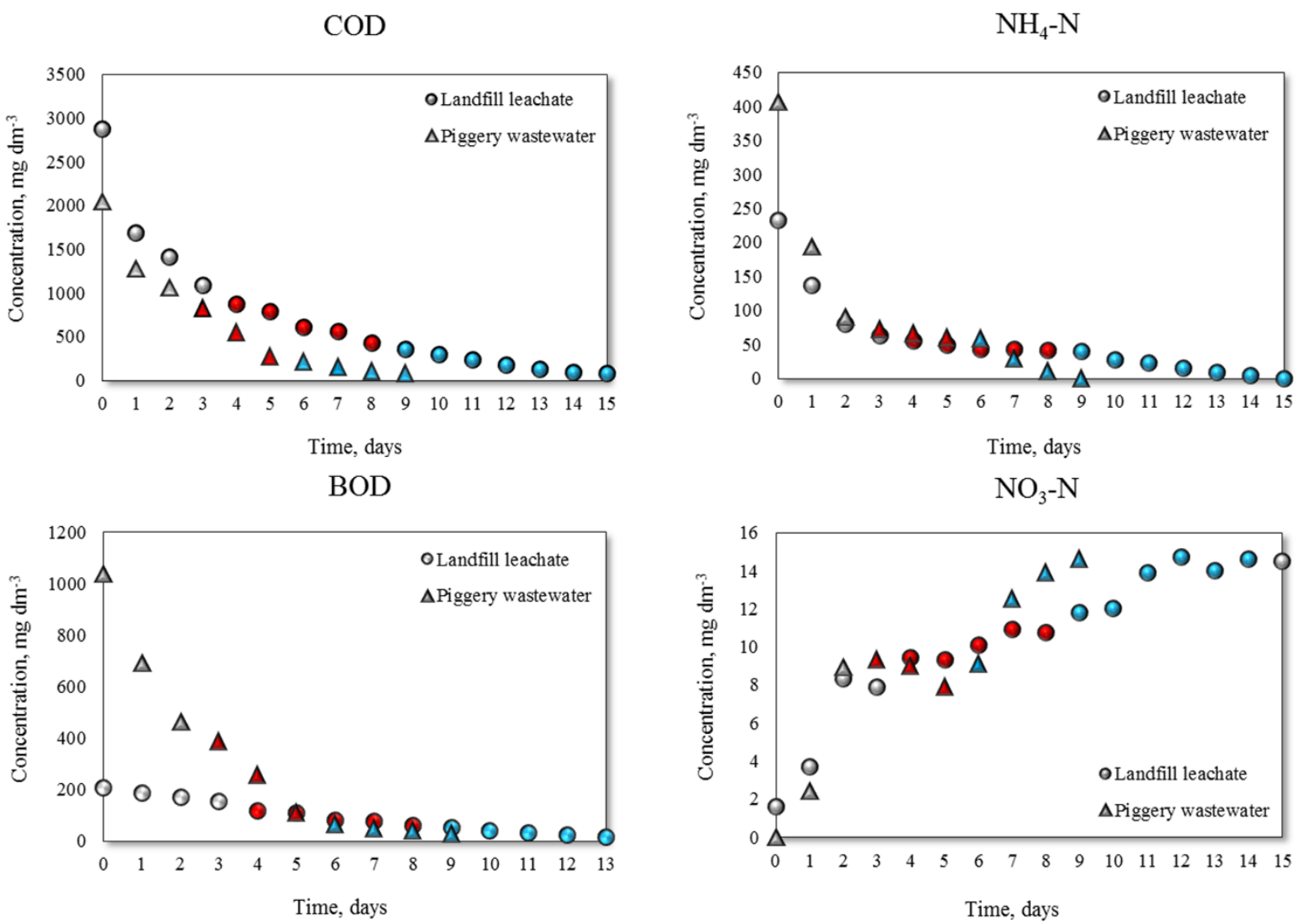

Fig. 2 Variation of $\mathrm{COD}, \mathrm{BOD}, \mathrm{NH}_{4}-\mathrm{N}$ and $\mathrm{NO}_{3}-\mathrm{N}$.

As a whole, the treatment process of the piggery wastewater became faster than that of the landfill leachate. In a period of 9 and 15 days for piggery wastewater treatment and landfill leachate, respectively, were achieved the COD required limits according to the national legislation. The limits for BOD were reached during the wastewater treatment in the SVFW of the 9th and 12th day for piggery wastewater and landfill leachate, respectively. The results show that the elimination of the ammonium ions, contained in the piggery wastewater, becomes easier than that in the landfill leachate although their higher initial concentration. This effect is probably due to the higher concentration of organics in the piggery wastewater $(\mathrm{BOD} / \mathrm{COD}=$ $0.5)$. Total elimination of the $\mathrm{NH}_{4}-\mathrm{N}$ contained in the piggery wastewater became for a nine days and in the landfill leachate - for fifteen days. In the SVFW denitrification was not achieved due to the greater depth of the Phragmites australis root system. It is well known, that the plant roots released oxygen in the rhizosphere, which makes the denitrification process impossible.

\section{Conclusions}

Integrated laboratory system was studied for treatment of two types of wastewater, differed in their generation and pollution - piggery wastewater and landfill leachate.

It was established that for both wastewaters studied the values of the characteristics of interest are significantly decreased accompanied with odour elimination. 
Significantly higher value of the BOD/COD ratio in the piggery wastewater determines the more easily and faster purification of this type of water in the integrated laboratory system in comparison with the landfill leachate.

Complete nitrification of the $\mathrm{NH}_{4}-\mathrm{N}$ was achieved while a negligible elimination of $\mathrm{NO}_{3}-\mathrm{N}$ in biofilter was observed. In order to achieve total elimination of $\mathrm{NO}_{3}-\mathrm{N}$ it will be useful to add carbon source to the biofilter as well as to use a vegetation with a shallow root system and a larger area of the subsurface vertical flow wetland system, to prevent the penetration of the roots to a greater depth.

\section{References}

American Public Health Association et al. (1992) Standard methods for the examination of water and wastewater. 18th ed. Washington, D.C.

Bhalla B, Saini M, Jha M (2013) Effect of age and seasonal variations on leachate characteristics of municipal solid waste landfill. International Journal of Research in Engineering and Technology 02(08):223-232.

Burton S, Watson-Craik I (1998) Ammonia and nitrogen fluxes in landfill sites: applicability to sustainable landfilling. Waste Management and Research 16(41):41-53. doi: 10.1177/0734242X9801600106

Jetten M, Strous M, van de Pas-Schoonen K, Schalk J, van Dongen U, van de Graaf A, Logemann S, Gerard Muyzer van Loosdrecht M, Kuenen J (1999) The anaerobic oxidation of ammonium. Microbiology Reviews 22:421-437. http://dx.doi.org/10.1111/j.1574-6976.1998.tb00379.x

Joo H, Hirai M, Shoda M (2006) Piggery wastewater treatment using Alcaligenes faecalis strain No. 4 with heterotrophic nitrification and aerobic denitrification. Water Research 40:3029-3036. http://dx.doi.org/10.1016/j.watres.2006.06.021

Kim H, Choi W, Chae A, Park J, Kim H, Song K (2016) Evaluating integrated strategies for robust treatment of high saline piggery wastewater. Water Research 89:222-231. http://dx.doi.org/10.1016/j.watres.2015.11.054

Lavrova S, Koumanova B (2007) Polishing of aerobically treated wastewater in a constructed wetland system. Journal of the University of Chemical Technology and Metallurgy 42(2):195-200.

Lavrova S, Koumanova B (2014) Nutrients removal from landfill leachate in "wetland" system. Journal of Chemical Technology and Metallurgy 49(2):143-148.

Lee A, Nikraz H, Hung Y (2010) Influence of waste age on landfill leachate quality. International Journal of Environmental Science and Development 1(4):347-350.

Lee A, Nikraz H (2014) BOD:COD Ratio as an Indicator for Pollutants Leaching from Landfill. Journal of Clean Energy Technologies 2(3):263-266.

Li J, Meng J, Li J, Wang C, Deng K, Sun K, Buelna G (2016) The effect and biological mechanism of $\mathrm{COD} / \mathrm{TN}$ ratio on nitrogen removal in a novel upflow microaerobic sludge reactor treating manurefree piggery wastewater. Bioresource Technology 209:360-368. http://dx.doi.org/10.1016/j.biortech.2016.03.008

Limoli A, Langone M, Andreottola G (2016) Ammonia removal from raw manure digestate by means of a turbulent mixing stripping process. Journal of Environmental Management 176:1-10. http://dx.doi.org/10.1016/j.jenvman.2016.03.007

Melnyk A, Kuklińska K, Wolska L, Namieśnik J (2014) Chemical pollution and toxicity of water samples from stream receiving leachate from controlled municipal solid waste (MSW) landfill. Environmental Research 135: 253-261. http://dx.doi.org/10.1016/j.envres.2014.09.010

Mojiri A, Aziz H, Zaman N, Aziz S, Zahed H (2016) Metals removal from municipal landfill leachate and wastewater using adsorbents combined with biological method. Desalination and Water Treatment 57:2819-2833. http://dx.doi.org/10.1080/19443994.2014.983180

Renou S, Givaudan J, Poulain S, Dirassouyan F, Moulin P (2008) Landfill leachate treatment: Review and opportunity. Journal of Hazardous Materials 150:468-493. http://dx.doi.org/10.1016/j.jhazmat.2007.09.077

Sheridan B, Curran T, Dodd V, Colligan J (2002) Biofiltration of odour and ammonia from a pig unit a pilot-scale study. Biosystems Engineering 82(4):441-453. doi: 10.1006/bioe.2002.0083 
Strous M, Gerven E, Zheng P, Kuenen J, Jetten S (1997) Ammonium removal fom concentrated waste streams with the anaerobic ammonium oxidation (anammox) prosecco in different reactor configurations. Water Research 31(8):1955-1962. doi: 10.1016/S0043-1354(97)00055-9

Wang L, Xu J, Ma S, Zhao B, Zhang Z, Zhou X, Zhang H (2016) Biological nitrogen removal in a modified anoxic/oxic process for piggery wastewater treatment, Desalination and Water Treatment 57(24):11266-11274. http://dx.doi.org/10.1080/19443994.2015.1043592

Wiszniowski J, Robert D, Surmacz-Gorska J, Miksch K, Weber J (2006) Landfill leachate treatment methods: A review. Environmental Chemistry Letters 4:51-61. doi: 10.1007/s10311-005-0016-Z

Yamamoto T, Takaki K, Koyama T, Furukawa K (2008) Long-term stability of partial nitritation of swine wastewater digester liquor and its subsequent treatment by Anammox. Bioresource Technology 99(14):6419-6425. http://dx.doi.org/10.1016/j.biortech.2007.11.052

Zhang L, Zheng P, Tang C, Jin R (2008) Anaerobic ammonium oxidation for treatment of ammoniumrich wastewaters. Journal of Zhejiang University Science B. 9(5):416-426. doi: 10.1631/jzus.B0710590 